DOI: http://dx.doi.org/10.33846/hn50507

http://heanoti.com/index.php/hn

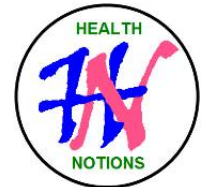

RESEARCH ARTICLE

URL of this article: http://heanoti.com/index.php/hn/article/view/hn50507

\title{
Understanding Role of Stunting Toddler Volunteers in Batu, Indonesia
}

\author{
Nurul Aini ${ }^{1(\mathrm{CA})}$, Aini Alifatin ${ }^{2}$, Ika Rizki Anggraini ${ }^{3}$ \\ ${ }^{1(\mathrm{CA})}$ Department of Nursing, Faculty of Health Science, Universitas Muhammadiyah Malang, Indonesia; \\ nurul_aini@umm.ac.id (Corresponding Author) \\ ${ }^{2}$ Department of Nursing, Faculty of Health Science, Universitas Muhammadiyah Malang, Indonesia; \\ alifatin@umm.ac.id \\ ${ }^{3}$ Department of Nursing, Faculty of Health Science, Universitas Muhammadiyah Malang, Indonesia; \\ ikarizki@umm.ac.id
}

\begin{abstract}
WHO determined the stunting tolerance (short-height), maximally $20 \%$ or a fifth of the whole toddler numbers. The initial report in 2018 showed 1,237 toddlers suffering stunting from the whole 14,285 toddlers in Batu. This research aims to describe the role of stunting toddler volunteers to accompany families with toddlers in Javanese Batu. This was a qualitative research with a phenomenological approach. The data were collected by in-depth interview. The data analysis results consisted of five research themes. They were: (a) the volunteers accompany the families by firstly detecting the stunting toddler indication, (b) the main focus of the volunteers was educating them about toddler-nutritious meals, (c) all participated volunteers were women, (d) the volunteers facilitated the communication and consultation for all the guided families, (e) their motivation to be volunteers was a social spirit to help each other and contribute to the community and social life. Generally, the volunteers had accompanied the family excellently. The given education by the volunteers consisted of toddler meal and nutrition and strategies to instill excellent behaviors for both the children and families.
\end{abstract}

Keywords: stunting; toddlers; volunteers; role

\section{INTRODUCTION}

\section{Background}

Stunting is a growth interruption in which children having improper height based on their growing period. It is caused by a chronic lack of nutrition during pregnancy. Any community should be aware of this situation, the increased rate of stunting occurrence from day today. Children suffering from stunting do not grow excellently due to their physical condition. It causes them to suffer an illness, having low academic capabilities, and making them seem not cleaver ${ }^{(1)}$. WHO determined the stunting tolerance (short-height), maximally $20 \%$ or a fifth of the whole toddler numbers. In Indonesia, 7.8 million of 23 million toddlers suffer stunting, approximately $35.6 \%$. A percentage of $18.5 \%$ is categorized very short while $17.1 \%$ is categorized short. This made WHO labeling Indonesia as a country with poor nutritional status ${ }^{(2)}$. In 2018, in East Java, a percentage of $2.1 \%$ toddler suffered stunting from the whole toddler numbers. This condition was almost found in every area. However, eleven areas become the focuses. One of them was the Great Malang. Experts explain the main cause of stunting is a chronic lack of nutrition during pregnancy. It covers incapability to provide nutritious meals due to lack of knowledge and information, environmental disturbance, economic deficiency, and socio-culture problems ${ }^{(3)}$.

Batu is a city with a significant rate of stunting toddler cases. The initial report in 2018 showed 1,237 toddlers suffering stunting from the whole 14,285 toddlers in Batu ${ }^{(3)}$. Empirically, Batu's socio-economic condition descriptions of the community are capable to support the needs of stunting toddlers. However, many cases of stunting toddlers are still found. Some cases are even undetected due to the community culture of villages in Batu. It considers children suffering illness should remain hidden and unknown by other people. The same thing also occurred in stunting toddlers. Most families denied that their toddlers were experiencing problems. This denial was based on various reasons and beliefs. One of them was - as long as the toddlers did not severely suffer 
from lesser height, they were fine with them. As long as they were considered to have nurtured the toddlers properly, it was fine for them. They were not aware of the stunting toddler occurrence was not caused instantly. It was begun in the pregnancy. Many stunting toddlers made the government, via the health agency, immediately took action to solve the problem. Several on-going programs are such as vitamin administration and the 1000-day accompaniment for pregnant and delivery women. They are promoted by involving related elements, such as family companion volunteers that have stunting toddlers. The volunteers had vital roles in the community. They directly went to the field to detect the stunting toddlers. They educated, advocated, and reported the stunting toddler patient development. They were prepared to accompany and monitor the patients at any time. How the volunteers carried out their roles were investigated in this research so that the problems could be identified and solved.

\section{Purpose}

A stunting toddler volunteer has important roles to prevent and control the occurrence of stunting toddlers. They carry out the accompaniment without being time-limited. Many types and characters of families were engaged. They have roles to detect, educate, suggest, and report the unsolved occurrence them. They surely require physical and psychological strength and durability. Therefore, this research aims to investigate how the volunteers acted. This research was expected to be capable of determining the more reliable strategy to improve the volunteers since they were the crucial parts of stunting state condition.

\section{METHODS}

The descriptive exploratory research design was used to investigate the volunteers' experience to carry out their roles on the field. This design was used to find out how the volunteers carried out their roles on the field to accompany the patients. The descriptive qualitative exploratory research was the useful initial stage to investigate a phenomenon. Thus, the obtained information would be useful for further investigations ${ }^{(4)}$. The data were collected by in-depth interview. It was very useful to support investigating the feelings and the participants' experience to reveal the demanded data.

This research was done from August until November 2020 and located in all work site of Batu Public Health Center, Eastern Java, Indonesia. The population of this research consisted of the stunting toddler volunteers in Batu. The participants were selected based on the inclusion criteria. The inclusion criteria consisted of the general characteristics of the subjects from an appropriate population based on this research ${ }^{(5)}$. The inclusion criteria were: the stunting toddler volunteers with minimally 6 months of services based on the local health center recommendation. The participants that were also the volunteers consisted of 20 persons. However, the participants were determined with the saturation point of the research data. The data investigation would be stopped once the saturation condition was achieved. The participants were selected by the purposive sampling technique. It is a technique to determine the participants based on the needs and applied criteria. Besides that, the researchers also used snowball sampling to determine the participants that met the required criteria based on information or recommendation from the previous participants. Thus, all participants were the best informants for the investigated phenomenon. Both purposive and snowball sampling are the most frequently used techniques to take samples in qualitative research ${ }^{(4)}$.

The data trustworthiness was used as a strategy to ensure the obtained data or information was valid in reflecting the events or cases in the research. The trustworthiness of qualitative research could be done by triangulating the method. It is a process of the same data or phenomena are reviewed from various perspectives ${ }^{(6)}$. The triangulation could be done with data cross-checking toward the respondents. This research applied the source and methodology triangulation so that the researchers could validate the data from various resources. They were such as validating the information about the main intervention given by the volunteers. The researchers crosschecked the information for all participants, the families of the stunting toddlers. On the other hand, methodological triangulation was done by validating the data with various data investigation methodologies. Besides the interview, there was direct observation of measuring height and weight and documentation of the patients' medical records. Then, to ensure the data's credibility, the researchers developed a trusted connection with the participants before getting the data. It was done to ensure the transparency and the correctness of the shared information. Then, the data of the research only took the trusted and experienced participants connected directly with this topic. It was to ensure the consistency and accuracy (dependability and confirmability) of the data. Thus, the researcher only involved the trusted participants who had experience and direct connection with the investigated topic.

The stages to collect the data were begun by asking permission from the Health Agency of Batu, Indonesia. Then, after the permission was published, the researcher contacted the Batu Public Health Center. Once the chief of the public health center welcomed the researcher, granted the permission, and accompanied the researcher, the researcher could access all required data. The data were about the participants, such as the names and addresses. 
The researcher obtained the data from the records in the local public health center. The researcher had provided inform consent sheet as the ethical consideration to participate and provide the data via interview.

\section{RESULTS}

\section{General Data of the Participants}

The initial obtained information consisted of the general data of the participants. The researchers obtained the general data of the participants before interviewing them based on the research focus. The demographical data consisted of initiation, sex types, age, and educational level. Here is the information of seven participating informants as the research data source. The obtained numbers were based on the data saturation of interview results.

Table 1. Description of the participants based on initiation, sex, age, educational and experience as the stunting toddler volunteers in Batu (interview results, August 2020)

\begin{tabular}{ccccc}
\hline Initiation & Sex & Ages (years) & Education & Roles \\
\hline AL & F & 27 & Bachelor & Volunteers \\
DT & F & 25 & Bachelor & Volunteers \\
ND & F & 14 & Bachelor & Volunteers \\
ZR & F & 26 & Diploma & Volunteers \\
AR & F & 30 & Diploma & Volunteers \\
PJ & F & 42 & High school & Volunteers \\
KK & F & 45 & High school & Volunteers \\
\hline
\end{tabular}

\section{The Mentoring Roles by Early Detection of the Stunting Toddler Symptoms}

Based on the direct interview results with the participants, generally, the participants accompanied them with main activities, such as measuring the height and weight of the toddlers. It was an attempt to ensure the condition and stunting status of the toddler. It was seen from this statement:

"I accompanied them face-to-face and online in terms of providing the nutrition for the stunting toddlers. I evaluated their growth for the recent six months, such as the height and weight for each month" (AL)

"I observed and cross-checked the initial data I obtained. I re-measured the weight and the height since most data were not valid" (DT)

"During my experience as a volunteer, I measured the weight and height. I educated them about stunting and its prevention” (ND)

"I accompanied the toddlers that were identified suffering stunting so that their weight and height would change. I did it by sharing their parents how to prepare complementary menus for toddlers" (AR)

\section{The Focused Material on Nutritious Meals for Stunting Toddlers Promoted by the Volunteers}

From the information and the interviews with the participants and the health care staff, there were various realizations done by the volunteers during educating the families. The volunteers educated them about nutrition, such as explaining the examples of meals for toddlers. They also focused on how to process and prepare the breast milk complimentary meals. This activity was found influenced by the roles of the volunteers at home. They were all described in these statements.

"I am happier to promote mini seminar with the toddlers by preparing alternative menus with high nutrition. It was to prevent and improve the stunting toddlers. I reminded the mothers to be always creative and innovative to support the nutrition necessities for their children every time I promoted a face-to-face activity at the integrated health care. I educated them to be more active, to be physically active, and to maximize their growth" (AL)

"I took the data of the family toddlers and surveyed their houses to see their conditions and their meals. I introduced them what should be improved" (DT) 
"Surely I did. I have toddlers and I will do anything to prevent and control the stunting condition. I provided the real examples about the process to prevent stunting. Thus, I provided direct examples, such as innovation of providing meals and taking care of problems since many complains that the stunting children did not want to eat and parents that did not carefully nurtured the toddlers. Then, I provided examples about providing high animalvegetable protein" $(Z R)$

"I tried to prevent and control. I also detected early and regularly screened and educated them how to provide meals for toddlers” (ND)

It was in line with a statement of other respondents as shown below:

"I told them the importance of nutrition and vitamin consumptions. I promoted stunting prevention acts for toddlers by providing complementary or boosting meals to increase the weight and height” (AR)

\section{All Volunteers were Women}

The volunteers were females. It might be due to better natural awareness and skills of females to approach toddlers. It was in line with the statement of the local health care staff.

"Heretofore, all volunteers are women and they are young mothers. They never give up and carefully treat the patients' families” (SS)

\section{The Excellent Communication and Consultation Promoted by the Volunteers}

Based on the interview with the participants, they optimally served the community. Their existences were strategic as references for community and families to get information assistance when they needed it. It could be seen from this statement.

"Insya allah when they contact me I will re-contact them via WA no matter what time it is, morning, during midday, or even evening” (KK)

"Thank god I work in a village health care, Sidomulyo, as the assistant. They sometimes met me and they also had my WA number. Thus, I could reply them anytime” (DT)

"I am ready if they call me anytime they need. It's okay to call me, in the morning or evening. I am ready for 24 hours because they are just like my family. We always keep in touch, ask, and discuss about their stunting toddlers" (ZR)

A similar statement and argument were also shared by the other respondents as shown below.

"as a volunteer, I need to be ready when they need me. They can contact me via WA" (ND)

“Anytime they needed me, I am ready. They can visit me anytime and I am ready to help" (PJ)

\section{The Social Motivation to Help Each Other and Contribute to Social Life}

Almost all participants were motivated to join the volunteers due to human-caring feelings, especially dealing with stunting toddler problems. The high rate of stunting toddlers in Batu touched their hearts to do something useful for the national generation survivability. It was also stated in these statements.

"I want to contribute for wider community. I use my status. I am a new midwife working for an institution and has not run my practice” (ZR)

"I personally wanted to control the stunting rate. Then, as a worker, I wanted to apply my knowledge and learn directly from the field" (DT)

"I could help the medical workers to decrease their workloads and also get knowledge. I knew how to deal with people whose different mindset” (ND) 
The same matters were also stated by other respondents. They had the same intention and sincerity to help each other. It was shown from these statements.

"The most important is seeking direct experience from the field and learn it there to face various types of people. Then, it is my realization of my devotion for the village or the area to decrease the stunting rate" $(A L)$.

"I wanted to help. I am feeling pity with the high stunting case rate. We as the medical workers want to decrease the rate” (AR).

"If it was not the Batu community, who should take care about it? It needed to be treated for better future and to avoid further disease and injuries" (KK)

\section{DISCUSSION}

\section{Early Stunting Detection Promoted by the Volunteers}

Based on the direct interview, the volunteers mainly did their main roles by early detecting the stunting condition of the toddlers. The regular detection was done by measuring the height and weight based on the Zscore formula. Thus, they could detect the patients' categories. A child was deemed to have under height standard if the measurement of height-for-age was under -2 standard of deviation. In another case, a child was deemed very short if the height-for-age was under than $-3 \mathrm{SD}^{(7)}$. Stunting could be diagnosed by the anthropometric index of height-for-age. It reflected the reached-linear growth during pre-and post- deliveries with long-term poor nutritional indication due to insufficient nutrition or health ${ }^{(8)}$. Generally, the volunteers were very useful to maintain the health service for the poor people ${ }^{(9)}$. Therefore, the government's recognition about the volunteers' performance would be important. There was a need of intervention to improve the productivity, responsiveness, and competence to overcome the rural-health officers or certain groups' needs, such as the female health workers or the certain aged volunteers' health ${ }^{(10)}$.

\section{The Main Focus of the Volunteers was Educating them about Toddler-Nutritious Meals}

When a child was detected to suffer stunting, the volunteers would focus more to carry out their roles within the educational frame for nutritious meal provision purposes (sufficient nutrition for toddlers). They educated about nutrition started by introducing the comestibles, comestible management, and strategy to instill excellent behaviors for children and families. They did so because not all stunting toddlers were from poor families. However, the main problem was the poor parental pattern factor. For example, the parents were busy and did not provide exclusive breast milk so that they brought their toddlers to unstandardized babysitting services. It was even worsened when the services did not have an excellent parental pattern to support the toddlers' nutritional needs.

Similar findings revealed that stunting significantly influenced children's health and development. The basic factor causing stunting condition could interrupt intellectual development and growth. The causal factors were such as low baby-born weight, insufficient breast milk, improper complimentary meals, repeated diarrhea, and respiratory infection. Based on the findings, most stunting children consuming unrecommended meals in terms of nutritional content were from poor families, with the highest numbers. They mostly settled in the outskirt and rural areas ${ }^{(9)}$.

The stunting factors were significantly correlated to life conditions. They were such as local political and economic conditions, educational status, community culture, food system, water condition, sanitation, and environment. The family economic statuses were influenced by several factors, such as parents' jobs, educational levels, and the number of family members. The economic level status of families would influence their family nutritional provisions and capabilities to gain health service access. Children from low economic levels had a greater risk of suffering stunting because of low nutritional provision and greater malnutrition risk. Lower educational levels of the parents also increased child-malnutrition risk. Parents' educational levels influenced their knowledge about nutrition and parental patterns. They were aware of improper parental patterns would increase stunting rate risk ${ }^{(10)}$.

\section{All Volunteers were Women}

The volunteers in Batu Health Agency were females. It might be due to better natural awareness and skills of females to approach toddlers ${ }^{(11)}$. Their mother instinct made them sensitive and feeling empathy for other individuals' problems moreover in this stunting toddler cases. They did it as if the stunting children were their kids ${ }^{(12)}$. Even so, there was also a possibility of male volunteers joining the action since the task was not limited 
in terms of gender ${ }^{(13)}$. The nature of mother, mother instinct, makes them sensitive and empathy toward other people moreover the stunting cases. They took care of the toddlers as if they were their children ${ }^{(14)}$. It was also possible to allow male volunteers to join because there was no limitation of gender ${ }^{(15)}$. The most important was the motivation and performance based on the actual expectation. The studies from the volunteers were important to succeed the health intervention. They could also be a partner for a health institution ${ }^{(16)}$. It was also supported with the health system of WHO to optimize the community health worker programs. One of them is by defining the roles of the community health cadres. It was also important to integrate the program into an appropriate general health system of the existing community ${ }^{(17)}$.The most important was appropriate motivation and performance on the field.

\section{The Excellent Communication and Consultation Promoted by the Volunteers}

Their loyalties to carry out their roles were excellent. Based on the interview with the participants, some of them optimally served the community. Their existences were strategic as references for community and families to get information assistance when they needed it. All participants admitted they voluntarily provided assistance and were ready to get contacted anytime when the patient families needed them. The benefits of communication as intervention given by the volunteers or cadres were realized into information sharing, education, home visit. They were excellent cooperation and could create trust toward the families. Thus, they would be cooperative to solve problems ${ }^{(18)}$.

The health and volunteer cadres to provide care for stunting cases became the main pillar. There was a slight difference between the cadre and volunteer roles. If the candidates only focused on the administrative process at the Integrated Health care Center, their tasks and roles would be limited at certain times. On the other hand, the volunteers kept acting on the field. They were the first party to recognize any development related to their mentored stunting toddlers ${ }^{(14)}$. Without their assistance, the villages' health services could not run excellently. Both volunteers and cadres should approach the community with minimum denials. Thus, they had to understand the characteristics and cultures of the community they lived in ${ }^{(8)}$.

\section{The Volunteers were Only Motivated to Help Each Other and Contribute to Social Life}

The high rate of stunting toddlers in Batu touched their hearts to do something useful for the national generation survivability. Almost all participants were motivated to join the volunteers due to human-caring feelings, especially dealing with stunting toddler problems.

According to, motivation occurs due to internal necessity condition. It leads to a feeling of satisfaction that encourages the individual ${ }^{(15)}$. It is in line with the volunteers' statements. They were satisfied while being involved on the field as volunteers. Motivation cannot be easily understood because it is an unseen internal matter of an individual. Even so, it is observable from an individual's behavior. Motivation has five characteristics: having inner energy within the human, being capable to trigger human behavior or organization, encouraging capabilities of the surrounding environment, encouraging potentials for humans to behave, and having capabilities to direct individuals to behave on a target focus. Thus, an individual's motivation in behaving could be felt when he had necessities to motivate his behavior. On the other hand, the environment motivated the individual. Later, it would empower their intensities ${ }^{(13)}$.

The motivation encouraging factors toward the individual and environmental factors. The individual factors only dealt with social responsibility, intrinsic satisfaction, success, motivation, and autonomy. Then, the environmental factors consisted of community and health system. For the community, the correlated matters were such as autonomous acknowledgment and income. Then, for the health system, the correlated matters were such as responsibility, workload, incentive, infrastructure, capital, training, supervising support, peer support, autonomy, and acknowledgment (16). The volunteers' participations were found positively correlated to performance. A study in Nepal found that the volunteers' roles could significantly contribute toward health family maintenance, especially dealing with blood pressures. The volunteers accompanied the patients during the intervention ${ }^{(23)}$. The health volunteers were also motivated by health reformations, such as the health sector policy. It could facilitate the objectives better and improve the motivation with several considerations, such as the design, the implementation of health sector reformation, solution to deal with workers' motivation, the recognition of communication importance and leadership, identification of organizational and cultural values to facilitate or hinder the reformation implementation, and understanding that reformation had different impacts on various health cadres ${ }^{(24)}$. The volunteers' motivations were also proved to have high solidarity. However, they kept carrying out the tasks professionally ${ }^{(24)}$.

The cadres and volunteers also admitted due to the supporting facilities, infrastructures, honors, and uniforms. Motivation, incentive, and training could encourage their excellent performances ${ }^{(17)}$. 


\section{CONCLUSION}

Based on the data analysis, five themes were found, such as (1) early detection of stunting toddlers, (2) providing nutritional meal education for stunting toddlers, (3) all volunteers were female, (4) facilitating communication and consultation (providing accessibility for patient families).

\section{REFERENCES}

1. Nurkomala S. SITI_NURKOMALA_22030113120041-min-1.2017.

2. Sakti SA. Pengaruh Stunting pada Tumbuh Kembang Anak Periode Golden Age. Biormatika: Jurnal Ilmiah Fakultas Keguruan dan Ilmu Pendidikan. 2020;6(1):169-75.

3. Dinkes Jatim. Profil Kesehatan Jawa Timur 2018. Surabaya: Dinas Kesehatan Provinsi Jawa Timur. 2019.

4. Isbister WH, Poses RM, Levitt NJ. Qualitative Research in Health Care. BMJ. 2000;320(7251):1729.

5. Gunawan I. Kualitatif Pendidikan. Malang: UM; 2013.

6. Hadi S. Pemeriksaan Keabsahan Data Penelitian Kualitatif pada Skripsi. J Ilmu Pendidik Univ Negeri Malang. 2017;22(1):109874.

7. Ramadhan K. Status Gizi Menurut Tinggi Badan per Umur pada Balita. Poltekita J Ilmu Kesehat. 2020;13(2):96-101.

8. Arsyati AM. Pengaruh Penyuluhan Media Audiovisual dalam Pengetahuan Pencegahan Stunting pada Ibu Hamil di Desa Cibatok 2 Cibungbulang. Promotor. 2019;2(3):182.

9. Viswanathan M, Kraschnewski JL, Nishikawa B, Morgan LC, Honeycutt AA, Thieda P, et al. Outcomes and Costs of Community Health Worker Interventions: A Systematic Review. Med Care. 2010;48(9):792-808.

10. Dieleman M, Harnmeijer JW. Improving-health-worker-performance_Dieleman_Harnmeijer. 2006;(September).

11. Rahmadhita K. Permasalahan Stunting dan Pencegahannya. J Ilm Kesehat Sandi Husada. 2020;11(1):225-9.

12. Black RE, Victora CG, Walker SP, Bhutta ZA, Christian P, De Onis M, et al. Maternal and Child Undernutrition and Overweight in Low-income and Middle-income Countries. Lancet. 2013;382(9890):427-51.

13. Timban JFJ, Tangkere EG, Lumingkewas JRD. Peran Perempuan dalam Pencegahan Stunting di Kecamatan Bunaken Kota Manado Provinsi Sulawesi Utara. Stud Soc Sci. 2019;2(1):8.

14. Dwi Kurnia D, Puji Mulyani W. Peran Ibu Pekerja dalam Perawatan Balita di Desa Selopamioro Kecamatan Imogiri Kabupaten Bantul. 2015;1-7.

15. Fitroh SF, Oktavianingsih E. Peran Parenting dalam Meningkatkan Literasi Kesehatan Ibu terhadap Stunting di Bangkalan Madura. J Obs J Pendidik Anak Usia Dini. 2020;4(2):610.

16. Heisler M, Lapidos A, Henderson J, Guzman RM, Wolfe J, Meyer P, et al. Study Protocol for a Community Health Worker (CHW)-led Comprehensive Neighborhood-focused Program for Medicaid Enrollees in Detroit. Contemp Clin Trials Commun. 2019;16:100456.

17. Cometto G, Ford N, Pfaffman-Zambruni J, Akl EA, Lehmann U, McPake B, et al. Health Policy and System Support to Optimise Community Health Worker Programmes: an Abridged WHO Guideline. Lancet Glob Heal. 2018;6(12):e1397-404.

18. Padmadas SS. Community-based Bundled Interventions for Reproductive and Child Health in Informal Settlements: Evidence, Efficiency, and Equity. Lancet Glob Heal. 2017;5(3):e240-1.

19. Nurhidayah I, Hidayati NO, Nuraeni A. Revitalisasi Posyandu melalui Pemberdayaan Kader Kesehatan. Media Karya Kesehat. 2019;2(2):145-57.

20. Torlesse H, Cronin AA, Sebayang SK, Nandy R. Determinants of Stunting in Indonesian Children: Evidence from a Cross-sectional Survey Indicate a Prominent role for the Water, Sanitation and Hygiene Sector in Stunting Reduction. BMC Public Health. 2016;16(1):1-11.

21. Wulandari HW, Kusumastuti I. Pengaruh Peran Bidan, Peran Kader, Dukungan Keluarga dan Motivasi Ibu terhadap Perilaku Ibu dalam Pencegahan Stunting pada Balitanya. J Ilm Kesehat. 2020;19(02):73-80.

22. Laili U, Andriani RAD. Pemberdayaan Masyarakat dalam Pencegahan Stunting. J Pengabdi Masy IPTEKS. 2019;5(1):8.

23. Neupane D, McLachlan CS, Mishra SR, Olsen MH, Perry HB, Karki A, et al. Effectiveness of a Lifestyle Intervention Led by Female Community Health Volunteers Versus Usual Care in Blood Pressure Reduction (COBIN): an Open-label, Cluster-randomised Trial. Lancet Glob Heal. 2018;6(1):e66-73.

24. Mathauer I, Imhoff I. Health Worker Motivation in Africa: The Role of Non-Financial Incentives and Human Resource Management Tools. Hum Resour Health. 2006;4:1-17. 